\title{
Sivas Ekolojik Koşullarında Yetiştirilen Türkiye Orijinli Yerel Bezelye \\ (Pisum sativum L.) Genotiplerinin Bazı Besin Elementi Içerikleri Bakımından Değerlendirilmesi
}

\author{
Tolga KARAKÖY*I (D), Ahmet DEMIRBAŞ' \\ 'Cumhuriyet Üniversitesi, Sivas MYO, Bitkisel ve Hayvansal Üretim Bölümü, SivAS.
}

Özet: Cumhuriyet Üniversitesi, Sivas Meslek Yüksekokulu, Bitkisel ve Hayvansal Üretim Bölümü, araştırma deneme alanında, 2016 yılı yetiştirme sezonunda yürütülen bu araştırmada; ülkemizin farklı bölgelerinden toplanmış olan toplam 8 I adet yerel bezelye genotipi ile 4 ticari çeşit Sivas ekolojik koşullarında besin elementi düzeylerinin saptanması amacı ile tesadüf blokları deneme desenine göre yetiştirilmiştir. Araştırmada, bezelye genotipleri ve ticari çeşitlerinde protein, fosfor (P), potasyum (K), demir (Fe), çinko $(\mathrm{Zn})$, bakır $(\mathrm{Cu})$ ve mangan $(\mathrm{Mn})$ gibi makro ve mikro besin elementi konsantrasyonları incelenmiştir.

Araştırma sonucunda bezelye genotipleri arasında besin elementi konsantrasyonları bakımından yüksek düzeyde varyasyona rastlanmıştır. Besin elementleri konsantrasyonları Protein (\% |4.19-28.8I), P (\%0.388-0.860), K (\%0.52-I.88), Fe (4I.0-690.2 $\mathrm{mg} / \mathrm{kg}), \mathrm{Zn}(28.7-103.4 \mathrm{mg} / \mathrm{kg}), \mathrm{Cu}(9.8-28.6 \mathrm{mg} / \mathrm{kg})$ ve $\mathrm{Mn}(\mathrm{I} 0.2-40.3 \mathrm{mg} / \mathrm{kg})$ arasında değişim göstermiştir. Bezelye yerel genotiplerinin besin elementi konsantrasyonları, ticari çeşitlerden önemli düzeyde yüksek bulunmuştur. Elde edilen bulgular, Türkiye orijinli bezelye genotiplerinin besin elementi konsantrasyonları bakımından oldukça yüksek düzeyde varyasyona sahip olduğu ve bu genotiplerin bezelye ıslah programlarında kalite özelliklerinin iyileştirilmesi için kullanılabileceğini göstermektedir.

Anahtar Kelimeler: bezelye, yerel genotip, besin elementleri

\section{Evaluation of Turkey Origined Local Pea (Pisum sativum L.) Genotypes Grown in Sivas Ecological Conditions in Term of Some Nutrient Contents}

Abstract: This research was conducted in the research field of Sivas Vocational School, Department of Plant and Animal Production, Cumhuriyet University. In this research, 81 local pea genotypes and 4 commercial varieties gathered from different regions of our country were grown in randomized complete block design with the aim of determining the level of nutrients. In the survey, macro and micro nutrient contents like nitrogen ( $N)$, phosphorus ( $P$ ), potassium (K), iron (Fe), zinc $(\mathrm{Zn})$, Cupric (Cu) and manganese (Mn) were examined in pea genotypes and commercial varieties.

As a result of the research, high level of variation was seen among genotypes in terms of nutrient content. Nutrient contents showed variance as protein (14.19-28.81\%), P (0.388-0.860\%), K (0.52-1.88\%), Fe (41.0-690.2 mg/kg), Zn (28.7- 103.4 mg/kg), Cu (9.8-28.6 mg/kg) and Mn (10.2-40.3 $\mathrm{mg} / \mathrm{kg}$ ). Nutrient content of pea local genotypes were considerably higher than those commercial varieties. The obtained findings indicate that Turkey origined pea genotypes have high level variation in terms of nutrient contents and these genotypes can be used in pea breeding program for improving quality features.

Keywords: pea, local genotype, nutrients element

\section{GiRiş}

Bezelye, Leguminosae (baklagiller) familyasında, Faboideae alt familyasında, Fabeae takımında, Pisum genusuna bağlı bir baklagil türüdür. Baklagiller, bitkiler alemi içerisinde 650 den fazla cins ve 18,000 tür ile üçüncü büyük familyayı oluşturmaktadırlar (Lewis ve ark., 2005). Bezelye, diploid kromozom sayısı $2 n=2 x=14$ olan, kendine döllenen ve haploid genom büyüklüğü 4.45 Gb olan önemli bir baklagil bitkisidir (Dolezel ve Greilhuber, 2010). Bezelye'nin orijin merkezinin birinci derecede Doğu Akdeniz, İran, Kafkasya, Afganistan ve Tibet'e kadar uzanan bölgeler, ikinci derecede de Güney Batı Arabistan üzerinden Etiyopya ve Kuzey Afrika'ya kadar uzanan bölgeler olduğu belirtilmiştir (Govorov, 1937; Davies, 1976 ve Hagedorn, 1984). Shoemaker (1953), Etiyopya'yı; Watts (1954), Etiyopya, Akdeniz kıyıları, Güney Batı Asya'yı, Höslin (1964), Akdeniz ülkelerini ve Etiyopya'nın bezelyenin gen merkezi olduğunu açıklamışlardır.

Baklagiller insan beslenmesinde temel protein ve karbonhidrat kaynaklarından olup, içerdikleri yüksek protein (\%।8-3I) ve önemli amino asitler nedeniyle, özellikle gelir düzeyi düşük ülkelerin en önemli protein kaynaklarından birisi olarak değerlendirilmektedir (Özdemir, 2002). Yemeklik tane baklagiller içerisinde önemli bir baklagil olan bezelye, içerdiği yüksek oranda protein ve vitaminlerden dolayı, yeşil ve kuru tane olarak tüketilmekte, ilave olarak unu çocuk mamasında ve çeşitli karışımlarda önemli besin maddesi olarak kullanılmaktadır. Bezelye tanesindeki kuru olgunluktaki protein oranı \% 18.0-28.4 arasında değişmekte olup, A ve B

vitaminleri yanında mineral maddeler yönünden de oldukça zengin bir bitkidir (Şehirali, 1988). Tarla bezelyesi tane, saman, silaj ve yeşil gübre olarak kullanılmaktadır. Fosfor ve kalsiyumca zengindir. Vitamin olarak $A$ ve $D$ vitamini yüksek olan bitki çiftlik hayvanlarının beslenmesinde ucuz ve kaliteli yem olarak vazgeçilmezdir (Tekeli ve Ateş, 2003). Singh ve ark. (20l0), 7I adet bezelye hattı üzerinde tohum ve un özelliklerinin farklılıklarını belirlenmesi üzerine yapmış oldukları araştırmada, 100 tane ağırlığının 4.26-29.30 gr, hidratasyon kapasitesinin 0.05-0.31 g/tohum, şişme kapasitesinin 0.02-0.76 ml/ tohum, pişme süresinin 45-8I dakika, nişastadaki amilaz miktarının \%24-58.3 ve kül miktarının \%2.24-3.73 arasında değiştiğini, kalite özellikleri bakımından incelenen 7I bezelye hattı arasında önemli farklııkların saptandığını bildirmişlerdir. Farklı ekolojik bölge ve yıllarda yetiştirilen bezelye çeşitlerinin kimyasal kompozisyonları arasındaki farklılıkları belirlemek amacıyla yapılan bir diğer çalışmada (Nikolopoulou ve ark., 2007), 3 farklı bezelye çeşidi, 2 farklı lokasyonda yetiştirilmiş, farklı yıl ve lokasyonda yetiştirilen bezelye çeşitlerinin sukroz, nişasta, polisakkarit miktarı, toplam tanin ve fitik asit konsantrasyonunun, iklim şartları, toprak özellikleri ve

\author{
*Sorumlu Yazar: tolgakarakoy73@hotmail.com \\ Geliş Tarihi: 31 Mart 2017 \\ Kabul Tarihi: 9 Ekim 2017
}


yetiştirildikleri bölgelere göre önemli derecede değişkenlik gösterdiğini belirtmişlerdir.

İçerdiği zengin besin maddeleri nedeniyle insan ve hayvan beslenmesinde önemli bir yere sahip olan bezelye, dünyada baklagiller içerisinde üretim bakımından fasulyeden sonra ikinci sırada yer alırken (Skyrpetz, 2004), ülkemizde ise nohut, mercimek, fasulye ve baklanın ardından beşinci sırada yer almaktadır. Ülkemiz bezelye yetiştiriciliği açısından oldukça elverişli ekolojik yapıya sahip olmasına rağmen, bezelye üretimi olması gereken seviyede değildir. Düşük üretimin en önemli nedenlerinden biride, ülkemizin farklı ekolojik bölgelerine uygun yüksek verimli ve kaliteli bezelye çeşitlerinin geliştirilememiş olmasıdır. Ülkemizde bezelyenin üretimdeki sorunların giderilmesi ve ihracatın artırılması yönünde gerekli tedbirlerin alınması gerekmektedir. Ekim alanın az olmasına paralel olarak, ülkemizde tarımı yapılan yemeklik baklagil cinsleri içerisinde bezelye, yerli tescilli çeşit sayısı bakımından en fakir olanıdı. Ülkemizde kuru tane amaçı kullanıma yönelik hiçbir tescilli çeşit yokken, taze tüketim amaçlı bugüne kadar I I adet çeşit, tescilli veya üretim izinli olarak piyasada yer almıştır. Bu çeşitlerden de sadece bir tanesi (Marmara) ülkemizde ıslah yoluyla geliştirilmiştir (Karayel ve Bozoğlu, 2008).

Yapılan bu çalışmada amaç, Türkiye orijinli yerel bezelye genotiplerinin, Sivas ili ekolojik koşullarında bazı besin elementleri bakımından genetik potansiyellerinin ortaya konabilmesi ve ıslah programlarında kullanılabilirliklerinin araştııılmasıdır.

\section{MATERYAL Ve YÖNTEM}

Cumhuriyet Üniversitesi, Sivas Meslek Yüksekokulu, Bitkisel ve Hayvansal Üretim Bölümü, araştırma deneme alanında, 2016 yllı yetiştirme sezonunda yürütülen bu araştırmada; ülkemizin farklı bölgelerinden toplanarak saflaştırılmış 81 adet yerel bezelye genotipi ile 4 ticari çeşit Sivas ekolojik koşullarında besin elementi düzeylerinin saptanması amacı ile tesadüf blokları deneme desenine göre yetiştirilmiştir. Materyallere ait detaylı bilgi Çizelge I'de verilmiştir.

Araştırmada, bezelye genotipleri ve ticari çeşitlerinden elde edilen tohumlarda protein, fosfor $(P)$, potasyum $(K)$, demir $(\mathrm{Fe})$, çinko $(\mathrm{Zn})$, bakır $(\mathrm{Cu})$ ve mangan $(\mathrm{Mn})$ gibi makro ve mikro besin elementi konsantrasyonları incelenmiştir. Bezelye genotiplerinin mineral madde miktarı tayininde ilk önce örnekler yaş yakma yöntemiyle analize hazırlanmıştır. Örneklerin parçalanması için yaklaşık $0.2 \mathrm{~g}$ numune yakma ünitesinin kabına tartılarak üzerine $5 \mathrm{ml} \% 65^{\prime}$ lik nitrik asit ve $2 \mathrm{ml} \% 35$ lik hidrojen peroksit ilave edilmiştir (GestoSeco ve ark., 2009; Bremner, 1965). Parçalama işleminin tamamlanmasından sonra elde edilen süzük mavi bant filtre kağıdından süzüldükten sonra çözelti hacmi ultra saf su ile $20 \mathrm{ml}$ ye tamamlanmıştır. Elde edilen bu süzükte P kolorimetrik olarak spektrofotometrede $882 \mathrm{~nm}$ 'de (Murphy ve Riley, 1962), K, Zn, Mn, Fe ve Cu AAS (Atomik Absorbsiyon Spektrofotometre) cihazı (Shimadzu AA-7000) ile belirlenmiştir (Kacar ve İnal, 2008). N konsantrasyonu ise Kjeldahl destilasyon yöntemine göre belirlenmiştir (Bremner, 1965). Analizler ekim yapılan her parselden 3 tekerrürlü olarak alınmış bitki örneklerinde, her tekerrür için ayrı ayrı yapııııştır.

\section{Ekim, Bakım ve Hasat İşlemleri}

Tarla denemesi, her bir genotipe ait tohumlar $2 \mathrm{~m}$ uzunluğundaki 4 sıraya, sıra arası $50 \mathrm{~cm}$, sıra üzeri $10 \mathrm{~cm}$ olacak şekilde, tesadüf blokları deneme desenine göre 3 tekrarlamalı olarak kurulmuştur. Ekimler markörle çiziler açılarak elle yapılmışır. Ekim ile birlikte deneme alanına $3 \mathrm{~kg} / \mathrm{da}$ saf azot, $6 \mathrm{~kg} / \mathrm{da}$ saf fosfor üzerinden gübre uygulanmış, fosfor kaynağı olarak triple süper fosfat (\%।8 N, \%46 fosfor), azot kaynağı olarak amonyum sülfat (\%2। N) gübresi kullanılmışır. Çıkıştan itibaren yabancı ot mücadelesi elle yolma ve çapalama şeklinde yapılmıştır. İncelenen özelliklerin tamamı ile gözlem-ölçümler ve hasat/harman işlemleri her parselde ortadaki iki sırada yapılmıştır. İstatistiki analizler SPSS paket programı kullanılarak gerçekleştirilmiştir.

Sivas ilinin denemenin yürütüldüğ̈̈ Mart 2016-Ağustos 2016 aylarına ait iklim değerleri Çizelge 2'de verilmiştir.

Çizelge 2'den izlendiği üzere araştırmanın yürütüldüğü Mart 2016-Ağustos 2016 ayları arasında en düşük ortalama sıcaklık değeri Mart ayında $\left(-5.3^{\circ} \mathrm{C}\right)$; en yüksek ortalama sıcaklık değeri ise Temmuz ayında $\left(37.0^{\circ} \mathrm{C}\right)$ saptanmışır. Denemenin yürütüldüğü yetiştirme yllında ise en düşük nispi nem değeri \%5।.8 değeri ile Ağustos ayında, en yüksek oransal nem değeri ise \%66.3 Mart ayında saptanmışır. Araştırma sürecinde gerçekleşen yağış miktarlarına bakıldığında ise en düşük değer Ağustos ayında $(6.3 \mathrm{~mm})$; en yüksek değer ise Nisan ayında $(61.4 \mathrm{~mm})$ saptanmıştır.

\section{Toprak Özellikleri}

Deneme toprağının fiziksel ve kimyasal özellikleri Çizelge 3'te verilmiştir. Deneme alanı toprağı, siltli killi tın bünyeye sahip, kireçli (\% 19.6) yarayışlı fosfor $\left(\mathrm{P}_{2} \mathrm{O}_{5}\right)$ içeriği düşük $(3.4 \mathrm{~kg} / \mathrm{da})$, hafif alkalin (7.28), organik madde içeriği düşük (\%।.7), tuzsuz

Çizelge I. Araştırmada kullanılacak yem bezelyesi hatları ile ticari çeşitlerine ait bilgiler

\begin{tabular}{|c|c|c|}
\hline No & Hat Sayısı & Orijin \\
\hline$T$ & 3 & Adiyaman-1988 \\
\hline 2 & 3 & Balıkesir-1995/10 \\
\hline 3 & I & Bursa-1995/10 \\
\hline 4 & 4 & Çanakkale-1995/10 \\
\hline 5 & 4 & Denizli-1980/09 \\
\hline 6 & 3 & Edirne-1995/10 \\
\hline 7 & 2 & Elazığ-1980/09 \\
\hline 8 & 2 & İstanbul-1980/09 \\
\hline 9 & I & Kars-1980/09 \\
\hline 10 & 4 & Kastamonu-1980/09 \\
\hline 11 & 4 & Kırklareli-I995/10 \\
\hline 12 & 2 & Malatya-1980/09 \\
\hline 13 & 2 & Manisa-1980/09 \\
\hline 14 & 2 & Sakarya-1980/09 \\
\hline 15 & 5 & Tekirdağ-1995/10 \\
\hline 16 & 2 & Tokat-1985/07 \\
\hline 17 & 4 & Afyon-1997/10 \\
\hline 18 & 2 & Bingöl-1997/I0 \\
\hline 19 & 2 & Diyarbakır-1997/10 \\
\hline 20 & 2 & Konya-1997/10 \\
\hline 21 & 2 & Karaman-2003/0I \\
\hline 22 & 3 & K. Maraş-2003/0I \\
\hline 23 & 2 & |sparta-2003/0| \\
\hline 24 & 1 & Burdur-2003/0I \\
\hline 25 & 4 & Bolu-2003/0I \\
\hline 26 & 2 & Van-2003/01 \\
\hline 27 & 3 & Hakkari-2003/0I \\
\hline 28 & 3 & Sivas-1985/07 \\
\hline 29 & 2 & Giresun-2003/01 \\
\hline 30 & 2 & Sinop-2003/01 \\
\hline 31 & 2 & Ordu $-2003 / 01$ \\
\hline 32 & I & Şırnak-2003/0I \\
\hline \multicolumn{3}{|c|}{ Toplam 81 } \\
\hline \multicolumn{3}{|c|}{ Ticari Ceșitler } \\
\hline $\mathrm{l}$ & Jof & Syngenta \\
\hline 2 & Karina & Nunhems \\
\hline 3 & Ulubatlı & Uludağ Üniversitesi \\
\hline 4 & Kirazlı & Uludağ Üniversitesi \\
\hline
\end{tabular}


Çizelge 2. Araştırmanın yürütüldüğü Sivas ilinin 2015-2016 bezelye yetiştirme dönemi bazı iklim değerleri

\begin{tabular}{|c|c|c|c|c|c|c|}
\hline \multirow[b]{2}{*}{ Meteorolojik Parametreler } & \multicolumn{6}{|c|}{ Aylar } \\
\hline & Mart & Nisan & Mayıs & Haziran & Temmuz & Ağustos \\
\hline Aylık Ort. Sicaklık ( $\left.{ }^{\circ} \mathrm{C}\right)$ & 4.6 & 9.8 & 14.8 & 17.1 & 22.6 & 22.8 \\
\hline Aylık Min. Sic. $\left({ }^{\circ} \mathrm{C}\right)$ & -5.3 & 0.9 & 4.6 & 9 & 11.8 & 12.8 \\
\hline Aylık Ort. Mak. Sıc. $\left({ }^{\circ} \mathrm{C}\right)$ & 16.4 & 22.7 & 27.6 & 33 & 37 & 35.3 \\
\hline Aylık Toplam Yağış (mm) & 43.9 & 61.4 & 51.3 & 20.2 & 10.2 & 6.3 \\
\hline Aylık Donlu Günler Sayısı & II & 9 & - & - & - & - \\
\hline Aylık Kar Örtülü Gün Sayısı & 2 & - & - & - & - & - \\
\hline Aylık Ortalama Nispi Nem (\%) & 66.3 & 61 & 60.6 & 54.5 & 51.9 & 51.8 \\
\hline
\end{tabular}

Kaynak: Devlet Meteoroloji İşleri Bölge Müdürlüğü Kayıtları, Sivas (Anonim, 2016)

(0.33 mmhos $/ \mathrm{cm})$, potasyum $\left(\mathrm{K}_{2} \mathrm{O}\right)$ içerikleri yüksek (93.59 $\mathrm{kg} / \mathrm{da})$, genel olarak mikro element içerikleri yeterlidir.

\section{BULGULAR ve TARTIŞMA}

Varyans analiz sonuçlarına göre, toplam 85 bezelye genotip ve çeşitleri arasında incelenen bazı besin elementleri konsantrasyonları bakımından önemli düzeyde farklılıklar olduğu saptanmıştır (Çizelge 4). Bezelye genotiplerinin protein konsantrasyonu değerleri incelendiğinde (Çizelge 4), protein konsantrasyonlarının \%।4.19-28.8I arasında değişim gösterdiğini, en düşük $N$ konsantrasyonu \%।4.19 ile Ordul genotipinde, en yüksek protein konsantrasyonunun ise \%28.8I ile Sivas3 genotipinde olduğu ortaya çıkmıştır. Ticari çeşitlerden Kirazlı \%23.44, Jof'un ise \%22.88 düzeyinde protein konsantrasyonuna sahip oldukları saptanmıştır.

Bezelye genotipleri tanede fosfor konsantrasyonları bakımından incelendiğinde (Çizelge 4), en düşük fosfor konsantrasyonu \%0.388 P ile Sivas I genotipinin, en yüksek fosfor konsantrasyonu \%0.860 P ile Hakkaril genotipinin sahip olduğu görülmektedir. Ticari çeşitlerden, Karina $\% 0.613$, Jof \%0.577, Ulubatlı \%0.44I ve Kirazlı \%0.4I 2 fosfor konsantrasyonuna sahip oldukları belirlenmiştir. Çalışmada yer alan diğer genotiplerden Balıkesir2, Kırklarelil, Sakarya2, Afyon2, Konya2, Isparta2 ve Sivas2 isimli genotipler sırasıyla, $\% 0.71$ I, \%0.704, \%0.709, \%0.725, \%0.757, \%0.784 ve \%0.744 $P$ değerlerine sahip olarak ön plana çıktıkları gözlenmektedir. Çizelge 4'ün incelenmesinden, bezelye genotiplerinin tanede potasyum konsantrasyonu bakımından değerlerin \%0.52I.88 K arasında değişim gösterdiği, en düşük potasyum konsantrasyonunun Kastamonu2 (\%0.58) genotipinde, en yüksek \%।.88 ile Kahramanmaraş। genotipinde bulunduğu tespit edilmiştir. Aynı çizelgeden bezelye ticari çeşitlerinden Karina \%।.74, Ulubatlı \%।.38, Kirazlı \%।.32 ve Jof \%।.30 potasyum konsantrasyonlarına sahip oldukları belirlenmiştir. Araştırma kapsamında incelenen bezelye genotiplerinin tanede demir konsantrasyonlarının 4I.0-690.2 mg/kg arasında değişim gösterdiği, en düşük demir konsantrasyonunun Adıyaman I (4l.0 mg/kg) bezelye genotipinde, en yüksek demir konsantrasyonunun ise $(690.2 \mathrm{mg} / \mathrm{kg})$ ile Tekirdağ I bezelye genotipinde olduğu saptanmıştır. Bezelye genotiplerinden Edirnel (225.l mg/kg), Hakkari2 (327.5 mg/kg) ve Sinop I ( $22.8 \mathrm{mg} / \mathrm{kg}$ ) demir konsantrasyonları bakımından yüksek değerlere sahip oldukları ve bu bakımdan yapılacak olan ıslah çalışmalarında kullanılabilecek materyaller olarak ön plana çıktıkları görülmektedir. Ticari çeşitlerden Ulubatlı, Jof, Kirazı,
Karina sırasıyla, $85.2 \mathrm{mg} / \mathrm{kg}, 83.7 \mathrm{mg} / \mathrm{kg}, 78.8 \mathrm{mg} / \mathrm{kg}$ ve 69.0 $\mathrm{mg} / \mathrm{kg}$ demir konsantrasyonuna sahip oldukları belirlenmiştir. Çizelge 4'ün incelenmesinden görüleceği gibi, tanede mangan konsantrasyonu bakımından elde edilen değerlerin 10.2-40.3 $\mathrm{mg} / \mathrm{kg}$ arasında değiştiği, en düşük mangan konsantrasyonuna Kırklarelil (I0.2 mg/kg) genotipinde rastlanırken, en yüksek mangan konsantrasyonuna Tekirdağl (40.3 mg/ kg) genotipinde rastlanmıştır. Ticari çeşitlerden Jof, Kirazlı, Ulubatlı, Karina sırasıyla, 20.3 mg/kg, 18.6 mg/kg, 14.8 mg/ $\mathrm{kg}$ ve $14.4 \mathrm{mg} / \mathrm{kg}$ mangan konsantrasyonuna sahip oldukları saptanmıştır.

Bezelye genotiplerinin tane bakır konsantrasyonu değerleri 9.8-28.6 mg/kg arasında değişim göstermiş, en yüksek bakır konsantrasyonuna 28.6 mg/kg ile Kahramanmaraş2 genotipi sahip olurken, en düşük bakır konsantrasyonu değerine 9.8 $\mathrm{mg} / \mathrm{kg}$ ile Adıyaman2 genotipinin sahip olduğu belirlenmiştir. Incelenen diğer genotiplerden Malatya2 $(20.9 \mathrm{mg} / \mathrm{kg})$, Tokat I (25.7 mg/kg), Diyarbakırl (26.9 mg/kg), Hakkari (23.9 mg/ $\mathrm{kg}$ ), Sivas2 (24.2 mg/kg), Giresunl (21.9 mg/kg) $20 \mathrm{mg} /$ kg'ın üzerinde bakır konsantrasyonu değerlerini aldıkları belirlenmiştir (Çizelge 4). Ticari çeşitlerden en yüksek bakır konsantrasyonu değerine $26.9 \mathrm{mg} / \mathrm{kg}$ değeri ile Ulubatlı çeşidi sahip olurken bu çeşidi sırasıyla Karina $(24.5 \mathrm{mg} / \mathrm{kg})$, Kirazlı (23.4 mg/ kg) ve Jof (17.4 mg/ kg) izlemiştir.

Bezelye genotiplerinin çinko konsantrasyonlarının 28.7-ı03.4 $\mathrm{mg} / \mathrm{kg}$ arasında değiştiği, en düşük çinko konsantrasyonuna sahip bezelye genotipinin $28.7 \mathrm{mg} / \mathrm{kg}$ ile Adryaman I genotipi olduğu, en yüksek çinko konsantrasyonunun ise $103.4 \mathrm{mg} / \mathrm{kg}$ ile Tekirdağ I genotipinin sahip olduğu belirlenmiştir. İncelenen diğer genotiplerden Malatya2 (95.l mg/kg), Tokat l (70.3 mg/ kg), Diyarbakır I (76.6 mg/kg), Sivas2 (75.6 mg/kg), Giresun I (73.5 mg/kg) 70 mg/kg'ın üzerinde çinko konsantrasyonuna sahip oldukları saptanmıştır (Çizelge 4). Bu değerler bezelye genotipleri arasındaki çinko konsantrasyonu yönünden varyasyonun ne kadar yüksek olduğunu göstermektedir. Çalışmada yer alan ticari çeşitlerden Ulubatlı $54.3 \mathrm{mg} / \mathrm{kg}$ çinko konsantrasyonuna sahip olurken, bu çeşidi Karina (52.3 mg/ kg), Kirazlı (39.7 mg/kg) ve Jof (38.7 mg/ kg) izlemiştir.

Ülkemizde yürütülen çeşitli araştırmalarda, Ozer ve ark. (20/2), ülkemizin farklı bölgelerinden toplanan 28 adet bezelye popülasyonun besin içeriklerinin belirlenmesine yönelik yürüttükleri çalışmalarda, bezelye popülasyonlarının K konsantrasyonlarının 764-1072 ppm, P konsantrasyonlarının 355-449 ppm, Ca konsantrasyonlarının 73.33-88.89 ppm, Cu konsantrasyonlarının 0.6-0.8

Çizelge 3. Deneme alanı topraklarının bazı fiziksel ve kimyasal özellikleri

\begin{tabular}{|c|c|c|c|c|c|c|c|c|c|c|c|c|c|}
\hline & & & & & & & & & & & & & \\
\hline Kum & Silt (\%) & Kil (\%) & ünye & $\begin{array}{c}\mathrm{pH} \\
(1: 2.5 \mathrm{H} 20)\end{array}$ & $\begin{array}{c}\text { Tuz } \\
\text { (mmhos/cm) }\end{array}$ & $\begin{array}{c}P_{2} \mathbf{O}_{5} \\
\left(\mathbf{k g} / d^{5} \mathbf{a}\right)\end{array}$ & $\begin{array}{c}\mathrm{K}_{\mathrm{O}} \mathrm{O} \\
(\mathrm{kg} / \mathrm{da})\end{array}$ & $\begin{array}{c}\text { Org. Mad. } \\
(\%)\end{array}$ & $\begin{array}{l}\text { Kireç } \\
(\%)\end{array}$ & $\begin{array}{c}\mathrm{Fe} \\
(\mathrm{mg} / \mathrm{kg})\end{array}$ & $\begin{array}{c}\mathrm{Zn} \\
(\mathrm{mg} / \mathrm{kg})\end{array}$ & $\begin{array}{c}\mathrm{Mn} \\
(\mathrm{mg} / \mathrm{kg})\end{array}$ & $\begin{array}{c}\mathrm{Cu} \\
(\mathrm{mg} / \mathrm{kg})\end{array}$ \\
\hline 14.6 & 48.3 & 37.1 & $\mathrm{SiCL}$ & 7.28 & 0.33 & 3.4 & 93.59 & 1.7 & 19.6 & 3.99 & 0.42 & 4.68 & 1.23 \\
\hline
\end{tabular}


Sivas Ekolojik Koşullarında Yetiştirilen Türkiye Orijinli Yerel Bezelye (Pisum sativum L.) Genotiplerinin Bazı Besin Elementi İçerikleri Bakımından Değerlendirilmesi

Çizelge 4. Türkiye orijinli bezelye genotip ve çeşitlerinin bazı besin elementi konsantrasyonlarına ait ortalama ve standart hata değerleri

\begin{tabular}{|c|c|c|c|c|c|c|c|}
\hline Genotip & Protein (\%) & Fosfor (\%) & Potasyum (\%) & Demir (mg/kg) & Mangan (mg/kg) & Bakır (mg/kg) & Cinko (mg/kg) \\
\hline Adiyaman I & $25.00 \pm 0.035$ & $0.409 \pm 0.01$ & $1.09 \pm 0.076$ & $41.0 \pm 1.484$ & $14.2 \pm 0.424$ & $10.9 \pm 0.494$ & $28.7 \pm 1.619$ \\
\hline Adiyaman2 & $23.19 \pm 0.268$ & $0.438 \pm 0.016$ & $0.93 \pm 0.127$ & $46.7 \pm 2.616$ & $14.8 \pm 0.636$ & $9.8 \pm 0.177$ & $30.9 \pm 0.601$ \\
\hline Adiyaman3 & $23.81 \pm 0.114$ & $0.472 \pm 0.038$ & $1.12 \pm 0.101$ & $43.0 \pm 2.116$ & $15.1 \pm 0.516$ & $11.4 \pm 0.521$ & $30.4 \pm 1.312$ \\
\hline Balıkesir I & $21.38 \pm 0.219$ & $0.518 \pm 0.014$ & $1.24 \pm 0.084$ & $44.5 \pm 2.404$ & $14.7 \pm 1.484$ & $11.3 \pm 0.636$ & $37.8 \pm 0.417$ \\
\hline Balıkesir2 & $23.00 \pm 0.212$ & $0.711 \pm 0.010$ & $1.75 \pm 0.148$ & $46.1 \pm 2.616$ & $11.9 \pm 1.555$ & $12.9 \pm 0.212$ & $43.1 \pm 0.714$ \\
\hline Balıkesir3 & $19.31 \pm 0.186$ & $0.651 \pm 0.030$ & $1.80 \pm 0.091$ & $51.3 \pm 2.321$ & $13.4 \pm 1.213$ & $14.2 \pm 0.524$ & $40.6 \pm 0.912$ \\
\hline Bursa & $24.13 \pm 0.169$ & $0.640 \pm 0.018$ & $1.49 \pm 0.262$ & $43.5 \pm 1.343$ & $15.8 \pm 0.919$ & $13.7 \pm 0.919$ & $35.6 \pm 1.583$ \\
\hline Çanakkalel & $24.81 \pm 0.084$ & $0.516 \pm 0.01$ & $1.24 \pm 0.276$ & $45.8 \pm 2.545$ & $16.0 \pm 0.777$ & $11.9 \pm 1.131$ & $46.7 \pm 1.053$ \\
\hline Çanakkale2 & $27.94 \pm 0.169$ & $0.600 \pm 0.02$ & $1.28 \pm 0.084$ & $56.8 \pm 1.767$ & $13.8 \pm 0.989$ & $13.3 \pm 0.353$ & $50.3 \pm 0.650$ \\
\hline Çanakkale3 & $23.19 \pm 0.146$ & $0.578 \pm 0.03$ & $1.63 \pm 0.106$ & $47.2 \pm 2.310$ & $15.0 \pm 1.221$ & $12.4 \pm 1.254$ & $50.4 \pm 1.226$ \\
\hline Çanakkale4 & $25.63 \pm 0.142$ & $0.503 \pm 0.01$ & $1.74 \pm 0.195$ & $48.2 \pm 2.954$ & $13.1 \pm 0.987$ & $13.6 \pm 0.745$ & $40.3 \pm 1.216$ \\
\hline Denizlil & $24.88 \pm 0.177$ & $0.550 \pm 0.016$ & $0.96 \pm 0.084$ & $49.3 \pm 1.343$ & $11.9 \pm 1.202$ & $11.2 \pm 0.490$ & $43.8 \pm 0.593$ \\
\hline Denizli2 & $25.25 \pm 0.142$ & $0.605 \pm 0.01$ & $0.82 \pm 0.289$ & $49.0 \pm 1.838$ & $12.9 \pm 1.484$ & $12.9 \pm 0.494$ & $37.6 \pm 0.579$ \\
\hline Denizli3 & $22.44 \pm 0.294$ & $0.584 \pm 0.01$ & $0.98 \pm 0.116$ & $48.4 \pm 1.465$ & $14.7 \pm 1.356$ & $14.6 \pm 0.853$ & $39.8 \pm 1.101$ \\
\hline Denizli4 & $24.06 \pm 0.446$ & $0.54 I \pm 0.028$ & $0.93 \pm 0.203$ & $51.4 \pm 1.545$ & $13.4 \pm 0.784$ & $13.7 \pm 1.214$ & $41.7 \pm 0.654$ \\
\hline Edirnel & $22.88 \pm 0.198$ & $0.485 \pm 0.012$ & $1.41 \pm 0.049$ & $225.1 \pm 3.889$ & $16.9 \pm 0.919$ & $16.9 \pm 1.202$ & $62.3 \pm 0.975$ \\
\hline Edirne2 & $21.94 \pm 0.283$ & $0.483 \pm 0.01$ & $1.34 \pm 0.056$ & $44.3 \pm 3.818$ & $14.9 \pm 1.202$ & $15.6 \pm 0.636$ & $49.9 \pm 0.275$ \\
\hline Edirne3 & $21.94 \pm 0.421$ & $0.532 \pm 0.012$ & $1.35 \pm 0.046$ & $58.2 \pm 2.345$ & $15.3 \pm 1.206$ & $15.3 \pm 0.844$ & $50.3 \pm 0.482$ \\
\hline Elazığ| & $23.25 \pm 0.092$ & $0.474 \pm 0.019$ & $1.04 \pm 0.103$ & $53.6 \pm 1.697$ & $15.2 \pm 0.707$ & $15.6 \pm 0.919$ & $48.7 \pm 0.388$ \\
\hline Elazığ2 & $24.00 \pm 0.155$ & $0.698 \pm 0.016$ & $1.55 \pm 0.085$ & $56.8 \pm 3.464$ & $15.6 \pm 0.707$ & $15.8 \pm 1.343$ & $66.2 \pm 0.671$ \\
\hline İstanbull & $24.88 \pm 0.155$ & $0.496 \pm 0.012$ & $1.72 \pm 0.191$ & $54.6 \pm 2.757$ & $15.4 \pm 1.131$ & $15.1 \pm 0.636$ & $51.5 \pm 1.456$ \\
\hline İstanbul2 & $27.13 \pm 0.198$ & $0.492 \pm 0.01$ & $1.81 \pm 0.085$ & $46.5 \pm 3.323$ & $14.5 \pm 0.494$ & $13.0 \pm 0.848$ & $35.6 \pm 1.060$ \\
\hline Kars & $25.63 \pm 0.169$ & $0.683 \pm 0.01$ & $1.27 \pm 0.127$ & $44.1 \pm 2.474$ & $13.6 \pm 1.131$ & $13.6 \pm 0.989$ & $31.2 \pm 0.700$ \\
\hline Kastamonul & $17.50 \pm 0.226$ & $0.597 \pm 0.01$ & $1.85 \pm 0.163$ & $43.7 \pm 3.181$ & $12.1 \pm 1.414$ & $15.8 \pm 1.202$ & $39.3 \pm 0.601$ \\
\hline Kastamonu2 & $20.63 \pm 0.219$ & $0.599 \pm 0.022$ & $0.52 \pm 0.085$ & $48.3 \pm 3.464$ & $14.5 \pm 1.131$ & $14.7 \pm 0.424$ & $42.9 \pm 1.216$ \\
\hline Kastamonu3 & $22.81 \pm 0.186$ & $0.562 \pm 0.022$ & $0.74 \pm 0.142$ & $51.2 \pm 3.041$ & $15.2 \pm 1.1245$ & $15.0 \pm 0.612$ & $50.2 \pm 1.384$ \\
\hline Kastamonu4 & $19.75 \pm 0.304$ & $0.603 \pm 0.02$ & $1.70 \pm 0.102$ & $50.7 \pm 2.144$ & $13.2 \pm 1.254$ & $14.4 \pm 0.903$ & $40.6 \pm 1.146$ \\
\hline Kırklareli I & $17.56 \pm 0.148$ & $0.704 \pm 0.010$ & $1.69 \pm 0.191$ & $42.6 \pm 1.484$ & $10.2 \pm 1.555$ & $17.6 \pm 0.848$ & $35.1 \pm 0.593$ \\
\hline Kırklareli2 & $26.31 \pm 2.248$ & $0.618 \pm 0.024$ & $1.54 \pm 0.219$ & $44.6 \pm 2.616$ & $14.9 \pm 0.919$ & $15.0 \pm 0.494$ & $43.5 \pm 0.961$ \\
\hline Kırklareli3 & $21.31 \pm 0.165$ & $0.614 \pm 0.019$ & $1.59 \pm 0.221$ & $43.1 \pm 1.804$ & $13.2 \pm 1.301$ & $14.6 \pm 0.724$ & $38.6 \pm 0.803$ \\
\hline Kırklareli4 & $18.63 \pm 0.175$ & $0.603 \pm 0.027$ & $1.49 \pm 0.204$ & $47.7 \pm 2.301$ & $13.5 \pm 0.856$ & $16.4 \pm 0.424$ & $40.1 \pm 1.024$ \\
\hline Malatyal & $27.56 \pm 0.778$ & $0.497 \pm 0.018$ & $1.12 \pm 0.212$ & $48.4 \pm 2.687$ & $19.9 \pm 0.919$ & $15.7 \pm 0.777$ & $54.9 \pm 1.187$ \\
\hline Malatya2 & $26.31 \pm 0.077$ & $0.554 \pm 0.016$ & $1.06 \pm 0.044$ & $79.3 \pm 2.333$ & $22.4 \pm 1.060$ & $20.9 \pm 1.484$ & $95.1 \pm 0.424$ \\
\hline Manisal & $21.81 \pm 1.163$ & $0.478 \pm 0.012$ & $1.30 \pm 0.325$ & $50.2 \pm 2.616$ & $16.4 \pm 1.131$ & $14.3 \pm 0.848$ & $52.9 \pm 0.898$ \\
\hline Manisa2 & $26.38 \pm 0.064$ & $0.545 \pm 0.036$ & $1.34 \pm 0.078$ & $61.8 \pm 2.969$ & $15.3 \pm 0.424$ & $17.9 \pm 0.989$ & $62.1 \pm 0.141$ \\
\hline Sakaryal & $24.00 \pm 0.205$ & $0.582 \pm 0.024$ & $1.30 \pm 0.085$ & $50.2 \pm 1.838$ & $14.9 \pm 1.202$ & $12.9 \pm 0.353$ & $43.4 \pm 0.919$ \\
\hline Sakarya2 & $23.50 \pm 0.354$ & $0.709 \pm 0.023$ & $1.50 \pm 0.191$ & $52.6 \pm 1.979$ & $14.9 \pm 0.494$ & $15.6 \pm 0.919$ & $52.5 \pm 0.643$ \\
\hline Tekirdağ I & $20.56 \pm 0.106$ & $0.659 \pm 0.011$ & $1.54 \pm 0.156$ & $690.2 \pm 7.141$ & $40.3 \pm 0.919$ & $15.6 \pm 0.919$ & $103.4 \pm 0.643$ \\
\hline Tekirdağ2 & $18.88 \pm 0.042$ & $0.52 \pm 0.019$ & $1.56 \pm 0.219$ & $43.0 \pm 2.687$ & $13.2 \pm 0.989$ & $13.5 \pm 0.282$ & $33.9 \pm 0.190$ \\
\hline Tekirdağ3 & $23.13 \pm 0.382$ & $0.527 \pm 0.01$ & $1.23 \pm 0.163$ & $53.9 \pm 1.484$ & $12.6 \pm 1.343$ & $15.1 \pm 1.343$ & $48.7 \pm 0.855$ \\
\hline Tekirdağ4 & $22.81 \pm 0.121$ & $0.512 \pm 0.022$ & $1.45 \pm 0.196$ & $50.6 \pm 2.274$ & $13.4 \pm 1.423$ & $13.9 \pm 0.789$ & $46.5 \pm 1.312$ \\
\hline Tekirdağ5 & $20.88 \pm 0.231$ & $0.498 \pm 0.01$ & $1.63 \pm 0.074$ & $56.5 \pm 2.145$ & $15.5 \pm 0.324$ & $16.2 \pm 0.743$ & $53.7 \pm 1.124$ \\
\hline Tokat I & $25.19 \pm 0.113$ & $0.620 \pm 0.023$ & $1.42 \pm 0.283$ & $100.3 \pm 1.343$ & $15.9 \pm 0.989$ & $25.7 \pm 1.979$ & $70.3 \pm 0.304$ \\
\hline Tokat2 & $21.88 \pm 0.205$ & $0.561 \pm 0.019$ & $1.36 \pm 0.106$ & $54.0 \pm 1.697$ & $13.8 \pm 1.484$ & $16.9 \pm 1.484$ & $43.5 \pm 0.615$ \\
\hline Afyon I & $26.25 \pm 0.233$ & $0.494 \pm 0.019$ & $1.48 \pm 0.169$ & $62.7 \pm 2.333$ & $16.4 \pm 0.565$ & $19.2 \pm 0.494$ & $48.1 \pm 0.332$ \\
\hline Afyon2 & $|4.8| \pm 0.26 \mid$ & $0.725 \pm 0.016$ & $1.73 \pm 0.049$ & $50.3 \pm 1.909$ & $14.8 \pm 1.202$ & $14.8 \pm 0.848$ & $38.7 \pm 0.360$ \\
\hline Afyon3 & $22.56 \pm 0.310$ & $0.604 \pm 0.024$ & $1.62 \pm 0.072$ & $49.2 \pm 1.472$ & $|4.1 \pm 1.04|$ & $13.4 \pm 0.526$ & $45.4 \pm 0.74 \mid$ \\
\hline Afyon 4 & $23.31 \pm 0.298$ & $0.682 \pm 0.013$ & $1.70 \pm 0.075$ & $520.6 \pm 1.719$ & $14.2 \pm 0.372$ & $15.2 \pm 0.816$ & $49.2 \pm 0.752$ \\
\hline Bingöll & $20.56 \pm 0.354$ & $0.569 \pm 0.019$ & $1.61 \pm 0.268$ & $55.7 \pm 2.899$ & $13.8 \pm 1.555$ & $15.3 \pm 4.464$ & $39.2 \pm 0.721$ \\
\hline Bingöl2 & $21.63 \pm 0.353$ & $0.668 \pm 0.01$ & $1.24 \pm 0.085$ & $50.6 \pm 2.616$ & $16.8 \pm 1.131$ & $13.7 \pm 0.565$ & $39.2 \pm 0.643$ \\
\hline Diyarbakır I & $22.00 \pm 0.311$ & $0.675 \pm 0.018$ & $1.39 \pm 0.092$ & $90.7 \pm 2.050$ & $15.6 \pm 0.636$ & $26.7 \pm 1.697$ & $76.6 \pm 0.947$ \\
\hline Diyarbakır2 & $25.88 \pm 0.190$ & $0.487 \pm 0.017$ & $0.94 \pm 0.084$ & $50.6 \pm 3.040$ & $14.7 \pm 0.777$ & $13.3 \pm 0.989$ & $60.6 \pm 0.954$ \\
\hline Konyal & $17.44 \pm 0.31 \mid$ & $0.555 \pm 0.026$ & $0.85 \pm 0.148$ & $49.0 \pm 1.555$ & $12.1 \pm 0.353$ & $15.1 \pm 0.636$ & $40.9 \pm 0.226$ \\
\hline Konya2 & $26.25 \pm 0.233$ & $0.757 \pm 0.031$ & $1.11 \pm 0.297$ & $59.1 \pm 2.404$ & $17.3 \pm 0.989$ & $16.1 \pm 0.636$ & $56.8 \pm 0.417$ \\
\hline Karaman I & $21.94 \pm 0.254$ & $0.514 \pm 0.019$ & $0.85 \pm 0.212$ & $41.1 \pm 1.909$ & $11.1 \pm 1.060$ & $13.2 \pm 0.989$ & $32.2 \pm 0.997$ \\
\hline Karaman2 & $16.38 \pm 0.19 \mid$ & $0.542 \pm 0.027$ & $1.21 \pm 0.219$ & $51.7 \pm 2.474$ & $14.5 \pm 0.636$ & $15.4 \pm 0.494$ & $41.1 \pm 1.110$ \\
\hline K.maraş I & $21.25 \pm 0.354$ & $0.676 \pm 0.037$ & $1.88 \pm 0.255$ & $60.5 \pm 1.838$ & $14.6 \pm 0.424$ & $17.6 \pm 1.484$ & $57.1 \pm 0.205$ \\
\hline K.maraş2 & $24.75 \pm 0.120$ & $0.665 \pm 0.041$ & $1.60 \pm 0.247$ & $97.3 \pm 1.909$ & $15.9 \pm 0.919$ & $28.6 \pm 1.979$ & $58.7 \pm 1.187$ \\
\hline K.maraş3 & $32.75 \pm 0.112$ & $0.856 \pm 0.019$ & $1.72 \pm 0.304$ & $59.9 \pm 1.456$ & $16.1 \pm 0.657$ & $19.8 \pm 0.553$ & $56.4 \pm 0.842$ \\
\hline Ispartal & $19.63 \pm 0.452$ & $0.590 \pm 0.032$ & $1.45 \pm 0.163$ & $49.9 \pm 2.899$ & $15.9 \pm 1.202$ & $15.2 \pm 0.707$ & $35.5 \pm 0.643$ \\
\hline Isparta2 & $15.56 \pm 0.282$ & $0.784 \pm 0.043$ & $1.82 \pm 0.198$ & $50.2 \pm 1.060$ & $17.1 \pm 0.353$ & $18.7 \pm 1.060$ & $51.2 \pm 0.205$ \\
\hline Burdur & $17.56 \pm 0.19 \mid$ & $0.691 \pm 0.010$ & $1.46 \pm 0.142$ & $47.1 \pm 0.848$ & $12.5 \pm 0.989$ & $14.6 \pm 0.636$ & $33.9 \pm 0.403$ \\
\hline Bolul & $|4.56 \pm 0.43|$ & $0.522 \pm 0.024$ & $1.31 \pm 0.177$ & $39.4 \pm 1.555$ & $14.7 \pm 1.343$ & $14.7 \pm 0.424$ & $31.9 \pm 0.806$ \\
\hline Bolu2 & $23.44 \pm 0.346$ & $0.638 \pm 0.035$ & $1.34 \pm 0.127$ & $53.9 \pm 2.687$ & $14.8 \pm 0.777$ & $17.7 \pm 0.989$ & $44.1 \pm 1.131$ \\
\hline Bolu3 & $18.31 \pm 0.354$ & $0.545 \pm 0.034$ & $1.47 \pm 0.152$ & $43.6 \pm 1.302$ & $16.2 \pm 1.396$ & $16.3 \pm 0.521$ & $42.3 \pm 0.64 I$ \\
\hline Bolu4 & $17.63 \pm 0.364$ & $0.522 \pm 0.04$ & $1.52 \pm 0.182$ & $47.2 \pm 1.306$ & $14.9 \pm 1.40 \mid$ & $15.6 \pm 0.424$ & $36.9 \pm 0.806$ \\
\hline Vanl & $17.31 \pm 0.219$ & $0.597 \pm 0.015$ & $1.08 \pm 0.162$ & $53.3 \pm 2.192$ & $17.5 \pm 0.777$ & $17.6 \pm 0.848$ & $48.1 \pm 1.110$ \\
\hline Van2 & $21.88 \pm 0.368$ & $0.510 \pm 0.012$ & $0.93 \pm 0.056$ & $52.1 \pm 2.404$ & $17.0 \pm 0.494$ & $14.8 \pm 0.353$ & $41.1 \pm 1.088$ \\
\hline Hakkaril & $24.31 \pm 0.170$ & $0.860 \pm 0.016$ & $0.92 \pm 0.241$ & $59.1 \pm 1.202$ & $16.9 \pm 0.989$ & $15.9 \pm 0.919$ & $50.3 \pm 0.721$ \\
\hline Hakkari2 & $25.50 \pm 0.212$ & $0.563 \pm 0.028$ & $1.20 \pm 0.233$ & $327.5 \pm 6.010$ & $18.7 \pm 0.919$ & $23.9 \pm 1.484$ & $60.7 \pm 0.353$ \\
\hline Hakkari3 & $25.38 \pm 0.182$ & $0.678 \pm 0.017$ & $0.96 \pm 0.142$ & $60.9 \pm 1.402$ & $16.2 \pm 0.831$ & $18.3 \pm 0.762$ & $58.6 \pm 0.743$ \\
\hline Sivas I & $27.25 \pm 0.170$ & $0.388 \pm 0.019$ & $1.29 \pm 0.092$ & $50.9 \pm 1.555$ & $11.2 \pm 0.424$ & $15.3 \pm 0.989$ & $30.3 \pm 0.700$ \\
\hline Sivas2 & $28.50 \pm 0.170$ & $0.744 \pm 0.028$ & $1.50 \pm 0.148$ & $98.2 \pm 0.636$ & $17.4 \pm 1.555$ & $24.2 \pm 0.636$ & $75.6 \pm 0.417$ \\
\hline Sivas3 & $28.81 \pm 0.172$ & $0.502 \pm 0.029$ & $1.42 \pm 0.113$ & $61.2 \pm 1.314$ & $13.4 \pm 0.562$ & $17.2 \pm 0.805$ & $46.4 \pm 0.516$ \\
\hline Giresun I & $24.44 \pm 0.325$ & $0.647 \pm 0.017$ & $1.49 \pm 0.163$ & $71.4 \pm 1.414$ & $17.2 \pm 0.777$ & $21.9 \pm 1.626$ & $73.5 \pm 0.417$ \\
\hline Giresun2 & $22.13 \pm 0.296$ & $0.590 \pm 0.015$ & $0.96 \pm 0.148$ & $62.5 \pm 1.555$ & $18.6 \pm 1.555$ & $15.6 \pm 0.919$ & $40.2 \pm 0.657$ \\
\hline Sinopl & $15.13 \pm 0.205$ & $0.568 \pm 0.016$ & $1.00 \pm 0.074$ & $122.8 \pm 1.555$ & $16.4 \pm 0.777$ & $18.2 \pm 0.777$ & $48.3 \pm 0.339$ \\
\hline Sinop2 & $15.13 \pm 0.233$ & $0.722 \pm 0.043$ & $1.68 \pm 0.098$ & $60.5 \pm 1.484$ & $14.5 \pm 0.919$ & $19.7 \pm 1.060$ & $43.7 \pm 0.544$ \\
\hline Ordul & $14.19 \pm 0.205$ & $0.578 \pm 0.024$ & $1.58 \pm 0.176$ & $49.1 \pm 1.484$ & $14.3 \pm 1.060$ & $16.6 \pm 0.282$ & $37.1 \pm 0.968$ \\
\hline Ordu2 & $14.75 \pm 0.222$ & $0.603 \pm 0.034$ & $1.52 \pm 0.124$ & $55.2 \pm 1.341$ & $15.9 \pm 1.023$ & $17.9 \pm 0.902$ & $40.4 \pm 0.674$ \\
\hline Şırnak & $18.81 \pm 0.106$ & $0.625 \pm 0.04 \mid$ & $1.34 \pm 0.226$ & $78.6 \pm 1.555$ & $15.8 \pm 0.424$ & $18.9 \pm 1.979$ & $47.5 \pm 0.445$ \\
\hline \multicolumn{8}{|l|}{ Ticari Ceșitler } \\
\hline Jof & $22.88 \pm 0.169$ & $0.577 \pm 0.021$ & $1.30 \pm 0.177$ & $83.7 \pm 1.979$ & $20.3 \pm 0.565$ & $17.4 \pm 0.848$ & $38.7 \pm 0.480$ \\
\hline Karina & $18.00 \pm 0.077$ & $0.613 \pm 0.043$ & $1.74 \pm 0.212$ & $69.0 \pm 1.060$ & $14.4 \pm 1.131$ & $24.5 \pm 1.343$ & $52.3 \pm 0.346$ \\
\hline Ulubatlı & $18.50 \pm 0.063$ & $0.44 I \pm 0.026$ & $1.38 \pm 0.077$ & $85.2 \pm 1.131$ & $14.8 \pm 1.343$ & $26.9 \pm 1.767$ & $54.3 \pm 0.586$ \\
\hline Kirazlı & $23.44 \pm 0.233$ & $0.412 \pm 0.043$ & $1.32 \pm 0.155$ & $78.8 \pm 1.343$ & $18.6 \pm 1.626$ & $23.4 \pm 0.353$ & $39.7 \pm 0.332$ \\
\hline Kareler Ort. & $0.53 * *$ & $0.01 *$ & $2.91 * *$ & $68.5 * *$ & $4.67 * *$ & $1.84 * *$ & $50.8 * *$ \\
\hline
\end{tabular}

${ }^{*} p<0.05, * * p<0.01$ 
Çizelge 5. Araştırmada ele alınan bezelye genotiplerinde incelenen özellikler arası korelasyon katsayıları

\begin{tabular}{lcccccc}
\hline Ozellikler & $\mathbf{P}$ & $\mathbf{K}$ & $\mathbf{F e}$ & $\mathbf{Z n}$ & $\mathbf{C u}$ & $\mathbf{M n}$ \\
\hline Protein & $-0.1254^{*}$ & $-0.1990^{* *}$ & 0.011 & $0.2512^{* *}$ & -0.0363 & $0.1323^{*}$ \\
$\mathbf{P}$ & & $0.2429^{* *}$ & 0.0578 & $0.2124^{* *}$ & $0.1795^{*}$ & $0.1048^{*}$ \\
$\mathbf{K}$ & & & 0.0739 & 0.0985 & $0.2573^{*}$ & -0.0236 \\
$\mathbf{F e}$ & & & & $0.6303^{* *}$ & $0.8028^{* *}$ & $0.7935^{* *}$ \\
$\mathbf{Z n}$ & & & & & $0.7376^{* *}$ & $0.7005^{* *}$ \\
$\mathbf{C u}$ & & & & & & $0.7158^{* *}$ \\
\hline
\end{tabular}

Ppm, Mg konsantrasyonlarınınl20-180.5 ppm, Zn konsantrasyonlarının3.623-4.545 ppm arasında değerlere sahip olduğunu belirtmişlerdir.

Elde edilen bu bulgular, inceledikleri bezelye popülasyonları arasında besin elementi konsantrasyonları bakımından önemli varyasyonlar saptadıklarını bildiren Ozer ve ark. (2012)'nın bulguları ile kısmen benzerlik göstermektedir.

Bezelye genotip ve çeşitlerinin özellikler arası korelasyon katsayıları Çizelge 5'te verilmiştir. Protein konsantrasyonuna ait korelasyon katsayıları incelendiğinde, çinko (Zn) (0.25। 2**), mangan (Mn) (0.1323 olumlu ve önemli, fosfor $(P)\left(-0.1254^{*}\right)$ ve potasyum $(\mathrm{K})\left(-0.1990^{* *}\right)$ arasında negatif ve önemli ilişkiler saptanmıştır.

Aynı çizelgeden (Çizelge 5), fosfor (P) konsantrasyonu ile, potasyum $(\mathrm{K})\left(0.2429^{* *}\right)$, çinko $(\mathrm{Zn})\left(0.2124^{* *}\right)$, bakır $(\mathrm{Cu})$ $\left(0.1795^{* *}\right)$ ve mangan $(\mathrm{Mn})\left(0.1048^{*}\right)$ arasında olumlu ve önemli, potasyum (K) ile, bakır (Cu) (0.2573**) arasında olumlu ve önemli, demir (Fe) ile Çinko $(\mathrm{Zn})\left(0.6303^{* *}\right)$, bakır (Cu) $\left(0.8028^{* *}\right)$ ve mangan $(\mathrm{Mn})\left(0.7935^{* *}\right)$ arasında olumlu ve önemli, çinko $(\mathrm{Zn})$ ile bakır $(\mathrm{Cu})\left(0.7376^{* *}\right)$ ve mangan (Mn) (0.7005**) arasında olumlu ve önemli, bakır $(\mathrm{Cu})$ ile mangan (Mn) (0.7I58**) arasında olumlu ve önemli ilişkiler olduğu belirlenmiştir. Yapılan benzer çalışmalarda protein konsantrasyonu ile magnezyum $(\mathrm{Mg})$, fosfor $(\mathrm{P})$, çinko $(\mathrm{Zn})$ ve nişasta miktarı arasında olumlu önemli ilişkiler saptanmıştır (Özer ve ark., 20I0; Wang ve ark., 20I0; Arntfield ve ark., 2010). Özellikler arası ilişkilerin oluşumunda, genetik bağlantı ya da pleitropik etkileşimlerin payının yanında çevresel faktörlerinde önemli düzeyde etkilerinin olduğu bilinmektedir. Çevresel faktörler iki özellik arasında olumlu ya da negatif etkilerin oluşmasına neden olabilmektedir (Yücel ve ark., 2009).

\section{SONUÇ}

Yapılan çalışma sonucunda elde edilen bulgular, daha önce yapılan çalışmalarda elde edilen bulgularla örtüşmektedir. Araştırmada materyal olarak incelenen bezelye yerel genotiplerinin fosfor $(\mathrm{P})$, demir $(\mathrm{Fe})$ ve çinko $(\mathrm{Zn})$ konsantrasyonları bakımından geniş bir genetik varyasyona sahip oldukları ve bu varyasyonun amaca uygun bezelye ıslahında kullanılabileceğini göstermektedir.

\section{KAYNAKLAR}

Anonim (20I6) Devlet Meteoroloji İşleri Bölge Müdürlüğü Kayıtları, Sivas.

Arntfield SD, Beta T, Cenkowski S (2010) Hydration properties of different varieties of Canadian field peas (Pisum sativum) from different locations. Food Research International 43:520-525.

Bremner JM (1965) "Method of Soil Analysis. Part 2. Chemical and Microbiological Methods", American Society of Agronomy Inc. Madison, Wise S-I I 49-I I 78, USA.
Davies DR (1976) Peas, In: Simmonds N.W. (ed), volution of crop plants. Longman, London, pp. I72-174.

Dolezel J, Greilhuber J (2010) Nuclear genome size. Are we getting closer? Cytometry 77, 635-642.

Gesto-Seco, E.M., Moreda-Pineiro, A., Bermejo-Barrera, A. ve Barrera-Bermejo, P. 2009. "Multi-element determination in raft mussels by fast microwave-assisted acid leaching and inductively coupled plasma-optical emission spectrometry", Talanta, 72, I I78- I I85.

Govorov LI (1937) Pisum Pp. 23I-336 in N.I. Vavilov and E.V. Wulff, eds. Flora of Cultivated Plants. IV. Grain Leguminosae. State Agricultural Publishing Company, Moscow, Leningrad.

Hagedorn DJ (1984) Compendium of pea disases. University of Wisconsin-Madison.

Höslin SM (1964) Gemüsebau. Erzeugung und Absatz. Bayerischer Landwirtschaft verlag $\mathrm{Gm} \mathrm{BH}$, Munchen.

Kacar B, İnal A (2008). Bitki Analizleri. Nobel yayın dağıtım.

Karayel R, Bozoğlu H (2008) Türkiye'nin Farklı Bölgelerinden Toplanan Yerel Bezelye Populasyonunun Bazı Agronomik Özellikleri. OMÜ Zir. Fak. Dergisi, 2008, 23(I):32-38.

Lewis G, Schrirer B, Mackinder B, Lock M (2005) Legumes of the World; Royal Botanical Gardens: Kew, UK.

Murphy J, Riley JP (1962) A modified single solution for the determination of phosphate in natural waters. Analtica Chemica Acta 27, 31-36.

Nikolopoulou D, Grikorakis K, Stasini M, Alexis MN, Iliadis K (2007) Differences in chemical composition of field pea (Pisum sativum) cultivars: Effects of cultivation area and year. Food Chemistry 103(2007) 847-852.

Özdemir S (2002) Yemeklik Baklagiller. Hasad Yayıncılık, İstanbul.

Özer S, Karakoy T, Toklu F, Baloch FS, Kilian B, Özkan H (2010) Nutritional and physicochemical variation in Turkish kabuli chickpea (Cicer arietinum L.) landraces. Euphytica 175:237-249.

Ozer S, Tümer E, Baloch FS, Karakoy T, Toklu F, Ozkan H (20I2) Variation for nutritional and cooking properties among Turkish field pea landraces. J.Food Agric. Environ. 10, 324e329.

Shoemaker JS (1953) Vegatable growing. John Wiley and Sons Inc., New York, Chapman and Hall Ltd., London.

Singh N, Kaur N, Rana JC, Sharma SK (2010) Diversity in seed and flour properties in field pea (Pisum sativum) germplasm. Food Chemistry 122 (2010) 518-525.

Skrypetz S (2004) Dry peas: situation and outlook. Agriculture and Agri-Food Canada, Market Analysis Division. Biweekly Bulletin, (17): I-I0.

Şehirali S (1988) Yemeklik Tane Baklagiller Ders Kitabı. Ankara Üniversitesi Zir. Fak. Yayınları, No:224.

Tekeli AS, Ateş E (2003) Yield and its Components in Field Pea (Pisum arvense L.) Lines. Journal of Central European Agriculture, 4(4):313-318.

Wang N, Hatcher DW, Warkentin TD, Toews R (2010) Effect of cultivar and environment on physicochemical and cooking characteristics of field peas (Pisum sativum). Food Chemistry I 18:109- I 15.

Watts RL (1954) The vegatable growing business. Orange Judd Publishing Co. Inc., New York.

Yücel C, Baloch FS, Özkan H (2009) Genetic analysis of some physical properties of bread wheat grain (Triticum aestivum L. Em Thell). Turkish Journal of Agriculture and Forestry 33:525-535. 